\title{
Paideusis
}

\section{Towards Skillful Global Citizenship Education}

\section{Tram Truong Anh Nguyen}

Volume 21, numéro 1, 2013

Contemplative Practice, Education, and Socio-Political

Transformation (Part Two)

URI : https://id.erudit.org/iderudit/1071572ar

DOI : https://doi.org/10.7202/1071572ar

Aller au sommaire du numéro

Éditeur(s)

Canadian Philosophy of Education Society

ISSN

0838-4517 (imprimé)

1916-0348 (numérique)

Découvrir la revue

Citer cet article

Nguyen, T. (2013). Towards Skillful Global Citizenship Education. Paideusis, 21(1), 26-38. https://doi.org/10.7202/1071572ar

\section{Résumé de l'article}

This article examines the implications of aspects of Buddhist philosophy for contemporary Global Citizenship Education. With primary reference to the writings of Thich Nhat Hanh, it specifically considers Buddhist understandings of suffering, the doctrine of no-self, the notion of store-consciousness, and the law of karma. The article subsequently introduces a skillful global citizenship education that is built on three pillars; namely, skillful awareness of interdependence, skillful compassion, and skillful awareness of intention. (c) Tram Truong Anh Nguyen, 2013

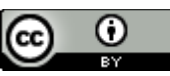

Ce document est protégé par la loi sur le droit d'auteur. L’utilisation des services d’Érudit (y compris la reproduction) est assujettie à sa politique d'utilisation que vous pouvez consulter en ligne.

https://apropos.erudit.org/fr/usagers/politique-dutilisation/ 
Paideusis, Volume 21 (2013), No. 1, pp. 26-38

\title{
Towards Skillful Global Citizenship Education
}

\author{
TRAM TRUONG ANH NGUYEN \\ University of Alberta, Canada
}

This article examines the implications of aspects of Buddhist philosophy for contemporary Global Citizenship Education. With primary reference to the writings of Thich Nhat Hanh, it specifically considers Buddhist understandings of suffering, the doctrine of no-self, the notion of store-consciousness, and the law of karma. The article subsequently introduces a skillful global citizenship education that is built on three pillars; namely, skillful awareness of interdependence, skillful compassion, and skillful awareness of intention.

\section{Issues to Consider in Global Citizenship Education}

As Andreotti and Souza (2012) observe, “[t]he concept of 'global citizenship' has become prominent in Europe and the Americas in government, civil society and educational discourses" (p. 1). Global citizenship can be broadly understood as " $[\mathrm{g}]$ aining the knowledge, skills and understanding of concepts and institutions necessary to become informed, active, responsible citizens" (UK's Department for Education and Skills, 2005 , p. 12). Although the question of what constitutes global citizenship is much debated in contemporary scholarship, many global citizenship education initiatives seem to converge in their pedagogical objectives. For example, in terms of knowledge, "peace and conflict" and "social justice" (Ahmad \& Szpara, 2005) are key "topics for knowledge and understanding" (Tarc, 2012, p. 115); as for skills, critical thinking, problemsolving, and conflict resolution skills are desired (Pike \& Selby, 1999; 2000; Tarc, 2012); tolerance and respect for diversity is an expected attitude (Tarc, 2012; Wright, 2012); and finally in terms of action, (direct or indirect) social and political engagement is encouraged (Dower, 2008; Schattle, 2008). Notably, in recent years a number of global citizenship education initiatives and practices have been established in North America that seek to provide students with international learning opportunities and increase their global awareness (Jefferess, 2012; Zemach-Bersin, 2007).

These initiatives and practices have much to offer in shaping students to become global citizens and disposing them toward democracy and social justice. However, postcolonial scholars have expressed concerns about the potential for the perpetuation of colonial or neo-imperial imaginaries in current global citizenship education. Specifically, programs to send students or development helpers abroad, with a helping imperative framed within a politics of benevolence, rather than emancipate those being "helped" may instead end up reproducing logics of colonialism/neo-imperialism (Cook, 2012; Jefferess; 2012; Tarc, 2012). Scholars have variously indicated a perceived confusion between empowerment and help (Cook, 2012; Zemach-Bersin; 2007) and between true political and social commitment and charity (Taylor, 2012). They have also drawn attention to a mixture of compassion and condescension that may appear on the part of the privileged helpers toward the "victims" of globalization (Wright, 2012). For some scholars, these problems may result from Eurocentric and dualistic conceptions of the self in which the "outside others" are those "whom we have

C Copyright 2013. Tram Truong Anh Nguyen assigns to Paideusis the right of first publication and educational and non-profit institutions a non-exclusive license to use this document for personal use and in courses of instruction provided that the article is used in full and this copyright statement is reproduced. Any other usage is probibited without the express permission of the author. 
used as repositories for what we have repudiated about ourselves" (Ellsworth, 2005, p. 90). Post-colonial writer Lisa Taylor (2012) has supported this point, offering some examples of "classed and racialized dichotomies constructed within colonial and neo-imperial discourses of globalization" (p. 184). For example, she points to how selves and others, from the perspective of the First World people, are presented as "we" who are "[s]uperior, developed, [and have] advanced technology" and "they" who are "[i]nferior, [u]nderdeveloped, backward" (p. 184). For other scholars, the issue may also come from ego-driven motives behind the act of helping (Cook, 2012; Zemach-Bersin; 2007). Notably, the I-Other dualism underlying these helping initiatives stands in danger of reinforcing the gaps between helper and helped:

Global citizenship provides the framework, or imaginary, for a horizontal comradeship; yet it nonetheless reinforces the distinction between the one-third and the two-thirds world. For Dower, the active global citizen is one who works to produce a better world; yet his examples ... figure this action as requiring an Other who needs to be known, understood and ultimately uplifted or saved. (Jefferess, 2012, p. 33)

Hence, a number of postcolonial scholars implicitly or explicitly suggest re-conceptualizing notions of self in ways that facilitate true engagement with "the other" or true political and social commitment, rather than encourage the mere "act of charity" (Taylor, 2012, p. 181) or "help" (Cook, 2012; Jefferess, 2012). Some authors specifically propose a strategy of destabilizing or disrupting the Eurocentric learning self (Ellsworth, 2005; Taylor, 2012). However, this is not an easy task:

The challenge of anticolonial global justice education lies in pedagogically provoking and sustaining this moment and space of epistemic vertigo, ontological loss and traumatic responsibility, from the ego's self-defense, from the refusal of relationality, from the consolation of familiar, hegemonic structures of authority and innocence. (Taylor, 2012, p. 180)

With reference to destabilizing the self or deconstructing the subject, Buddhist scholar Robert Hattam (2004) indicates that Buddhism might have something to offer:

The recent move toward theory of deconstructive subjectivity ... does suggest some promise even though, from a Buddhist perspective, it is difficult to see what "Western" theoretical resources can now be used to fill the void. But Buddhism does appear to have conceptual resources that could contribute to what is an urgent theoretical and practical problem. (p. 13)

In what follows, I address the potential of Buddhism to speak to and resolve some of the potential pitfalls of global citizenship education. Specifically, I discuss Buddhist insights into the impermanent and contingent nature and the origin of what is commonly believed in Western contexts to be "self." I then examine "the

helping imperative" in light of this Buddhist deconstruction of the self. Finally, I propose what I call "skillful global citizenship education" with the ultimate aim of enhancing individual and social well-being.

\section{Buddhist Conceptions of Suffering, (No)Self, and the Law of Karma}

In this section, I introduce three interrelated Buddhist concepts; namely "suffering," "(no)self," and the "law of karma." They are among basic concepts in Buddhism because they are from the core teachings of the Buddha (Bodhi, 2005; Mitchell, 2002; Nhat Hanh, 1998; Rahula; 1959; Williams, 2000).

\section{Suffering}

Central to the Buddha's teaching are the Four Noble Truths in which the Buddha addresses "suffering" (dukkha), points to its origin, and, finally, shows the way to cease suffering. In The First Noble Truth, the Buddha defines suffering: 
Birth is dukkha, old age is dukkha, sickness is dukkha, and death is dukkha. Sorrow, lamentation, dejection, and despair are dukkha. Contact with unpleasant things is dukkha, and separation from what one wishes is dukkha. In short, the Five Aggregates ${ }^{1}$ onto which one grasps are dukkha. (Mitchell, 2002, p. 47)

Put differently, "[t]his First Noble Truth ... proclaims that life as ordinarily lived is dissatisfactory" (Mitchell, 2002, p. 47). Although the Buddha does not deny the fact that people still have some happiness in life, this does not last long because everything, including "self," is impermanent. In The Second Noble Truth, the Buddha shows the origin of suffering. For him, the fact that everything is subject to change per se does not cause suffering. Rather, it is people's desires and efforts to grasp (impermanent) things that bring about their suffering. In other words, suffering comes from human ignorance of the impermanent and contingent nature of things and the resulting attachment to them. The Vietnamese Buddhist monk Thich Nhat Hanh (1998) offers an example: "When we are attached to a certain table, it is not the table that causes us to suffer. It is our attachment" (p. 21). Equally, "self" is also impermanent, but suffering actually comes, not from the idea that "I am unreal," but from the fact that "I keep trying to make myself real in ways that never work" (Loy, 2003, p. 27). For Buddhists, the effort to make the "self" real is like trying to fill up a bottomless hole. This failure entails insatiable thirst or craving. "Nothing we drink can ever assuage our tanha [thirst], because that thirst is due to an emptiness at the core of our being" (Loy, 2003, p. 27). According to the Buddha, there are three types of craving or thirst; namely, "the craving for sensual pleasure, the craving for continued becoming, and the craving for non-becoming (Mitchell, 2002, p. 48). Craving, accompanied by greed, hatred, and delusion, obviously causes suffering, but craving is not the primary cause of suffering. The primary cause is, as noted, human ignorance of the awareness that everything (self included) is impermanent and empty of an inherent essence. Because we are ignorant, we remain attached to notions of essence and permanence. However, the good news is that suffering can cease. In The Third Noble Truth, "the Buddha also associates the complete cessation of dukkha with the state Nirvana, which means "blowing out" or "extinguishing" the fire "that burns one's life with dissatisfaction" (Mitchell, 2002, p. 45). Specifically, "[w]hen craving ceases, its effect, namely dukkha, ceases and the result is Nirvana" (p. 50). It also means cessation of suffering is possible. Nhat Hanh (1998) affirms, "If there were no possibility of cessation, what is the use of practicing? The Third Truth is that healing is possible" (p. 11). The Fourth Noble Truth concerns the path to cessation, called by the Buddha the Noble Eightfold Path, which "leads to refraining from doing the things that cause us to suffer" (Nhat Hanh, 1998, p. 11). The Noble Eightfold Path consists of Right Understanding, Right Thought, Right Speech, Right Action, Right Livelihood, Right Effort, Right Mindfulness, and Right Concentration (Mitchell, 2002, p. 50). Note that herein "right" does not mean the opposite of "morally wrong" because, as Mitchell (2002) observes, the Buddha's teachings are not to be taken as a "religious duty" or command, but rather as a "specific method prescribed for curing the disease." Hence, "right" in this sermon means "skilful" (p. 51), where "skillful" can be broadly understood as "in accord with the truth of non-duality" In this spirit, according to Nhat Hanh (1996), the "right" liberation path must derive from suffering, or as generally metaphorically understood in Buddhism, lotus can only arise from mud. More specifically, travelling the Eightfold Path is the process of transforming the seeds of suffering and ignorance, which are existing in us, into peace and enlightenment. It is worth noting that all people are capable of so doing because, besides seeds of ignorance, seeds of awakenment are also already in us (Nhat Hanh, 1996). The important thing is how much and how far we are willing to, and hence able to, develop those positive seeds. Thus, the more skillful the practitioner is, the more (perceived) negative seeds he or she can transform into peace and joy (and, of course, the more awakening seeds he or she can cultivate), and the more enlightened he or she becomes. A similar understanding of "skillfulness" is also (implicitly) expressed in the Tibetan Buddhist scholar Khenpo Tsultrim Gyamtso Rinpoché's view on what he calls "the Progressive Stages of Meditation on the Emptiness" (1986). Explaining the stages of meditation and the consequent levels of enlightenment, he offers a nice metaphor:

\footnotetext{
${ }^{1}$ Please see p. 4 for an explanation of the Five Aggregates.
} 
One can think of the "Progressive Stages of Meditation on Emptiness" as the stages in the refinement process of a piece of gold ore. The initial stages of the process are somewhat gross but nonetheless effective, the later stages become more and more refined until finally the completely pure refined gold itself emerges. Here the gold is compared to the Absolute Truth of the Emptiness itself. (16)

This path is "skillful" because the more we practice the more we appreciate the truth of non-duality and the more our "gold," or awakened nature is revealed. Rinpoche characterizes these stages of meditation as a) listening to, b) reflecting on the Buddha's words, and c) meditating to have direct embodied experiences of the Buddha's teaching.

In sum, "skillfulness" transcends morally right-wrong dualism Hence, the Noble Eightfold Path refers to an on-going process, through different progressive stages, of transforming seeds of suffering and ignorance into peace and enlightenment (refining gold) and of cultivating seeds of awakening. In this sense, liberation from suffering is not only an end but also a process. From the characterization of the Eightfold Path we can see that Buddhist practice is all-encompassing, working with our actions and thoughts (intentions) as well as our speech. However, as I will elaborate below, it is of primary importance that the "right view" of (no)self be brought to and infused within all aspects of the path

\title{
(No)Self
}

For Buddhists, the belief that the self is a permanent and discrete entity is just a delusion. In fact, what we commonly take to be the "self" is comprised of impermanent constituents. Hence, Buddhism posits the notion of "no-self." Texts of multiple Buddhist traditions have seemingly different interpretations of the noself doctrine. However, as I will detail, there are five major themes that cut across the literature I have studied to date:

First, as many have discussed, the no-self doctrine denotes that "self" is impermanent because "self" is made of five aggregates bounded in a dynamic bundle conditioned by causes and conditions (Harvey, 1990; Mitchell, 2002; Nhat Hanh,1996; Williams, 2000). Mitchell (2002) explains the five aggregates as follows:

\begin{abstract}
The first of the Five Aggregates that constitute ordinary human selfhood is material "form" (rupa), or the body that is made up of impermanent material elements. These material elements are said ultimately to be produced by impermanent atoms of different types. The other four aggregates are the mental constituents of the functional self. The second aggregate is "sensation" (vedana) which includes sensations associated with the body as well as feelings. These sensations of felt experience are categorized as pleasant, unpleasant, or neutral. The third aggregate is "perception" (samjna; Pali: sanna), which includes the cognition and recognition of physical objects and of mental phenomena (ideas or thoughts). The fourth aggregate is "mental formations"(samskara; Pali: samkhara), which include the various mental states, attitudes, and dispositions that form the character of one's life. These are especially important mental factors because they include all the willful states of mind (cetana) that move one to do good and bad actions, and therefore result in good or bad karma. The fifth aggregate is "consciousness" (vijnana; Pali: vinnana), which includes mental awareness and discrimination. (p. 38)
\end{abstract}

A close examination of the five aggregates reveals that nothing is permanent. The five aggregates are brought into being or to cessation by causes and conditions, what is called the principle of dependent co-arising. As the Samyutta-kikaya, a Buddhist scripture, describes "That being, this comes to be; from the arising of that, this arises. That being absent, this is not; from the cessation of that, this ceases" (Samyutta-kikaya, II, 28, as cited in Mitchell, 2002, p. 39). Mitchell (2002) adds, "[t]his general principle of conditionality simply states that all things arise and pass away due to certain conditions" (p. 39). Likewise, Williams (2000) notes, "the putative 'Self' (if it occurs at all) occurs as a result of the coming together of causal conditions. It accordingly could not be unchanging" (p. 63).

Second, the no-self doctrine affirms the interrelatedness of all beings. This belief is reflected in the Heart Sutra-a popular sutra in Mahayana Buddhism which states that form is emptiness and emptiness is form. Nhat Hanh coined the term "inter-being" (Nhat Hanh, 1996; Nhat Hanh, 1997) to express the meaning of the 
sutra. Inter-being references the interconnectedness of all beings and denies the existence of a separate self. He provides a by now well-known example:

Our sheet of paper is empty ... it is empty of a separate, independent existence. It cannot just be by itself. It has to inter-be with the sunshine, the cloud, the forest, the logger, the mind, and everything else. It is empty of a separate self. But, empty of a separate self means full of everything. (1997, p. 10)

Herein, note that emptiness or nothingness in Buddhism is not equated with nihilism, which is understood as relative nothingness or the negation of eternalism. The emptiness or nothingness in the no-self doctrine is the absolute Nothingness, or "the middle way of emptiness between eternalism and nihilism" (Odin, 1996, p.97). In terms of interdependence, Loy (2003) also expresses a similar view, "We are interdependent because we are all part of each other, different facets of the same jewel we call the earth" (p. 108).

Third, the no-self doctrine connotes a conception of subject-object non-duality (Grant, 2009; Loy, 2003; Nhat Hanh, 1996; Pawle, 2009; Williams, 2000). Pawle (2009) explains:

\begin{abstract}
No-self in this sense is an ability of mind to function in such a way as to allow for mental states to lose their person-based characteristics and their characteristic of subject perceiving object. Having "no substance" refers to mind being able to function without a fixed sense of self. Subject-object mental states can disappear and a mental state of oneness can arise. (p. 49)
\end{abstract}

Nhat Hanh (1996) argues that, with an illusion of an independent ego-self, the mind constructs the subjectobject divide. Because we discriminate between ourselves and others, we engage in dual thinking and other resulting discrimination. By contrast, no-self is a potential of mind that "gives a person the possibility of dropping self-centered orientation, to be truly open psychologically, and to experience from a perspective that is much bigger than a limited personal one" (Pawle, 2009, p. 49). In short, it can be understood that no-self is synonymous with non-duality, and as "[n]on-duality denies all relative and opposite concepts" (Sadakata, 1997, p. 79), for Buddhists, it "is a philosophy of the absolute" (p. 80).

Fourth, no-self correlates with compassion. Buddhists argue that it is the sense of ego-self that separates people. By contrast, " $[\mathrm{t}]$ he Buddha found in his own Awakening that the realization of the absence of such a permanent self leads to selfless loving kindness and compassion for others" (Mitchell, 2002, p. 37). Understandably, when the ego is broken, the Awakening Mind arises. This event is "a fundamental switch in orientation from self-concern to concern for others, to compassion" (Williams, 2000, p. 176). Nhat Hanh (2008) affirms:

So as you progress on the path of insight into non-self, the happiness brought to you by love will increase. When people love each other, the distinction, the limits, the frontier between them begins to dissolve, and they become one with the person they love. There's no longer any jealousy or anger, because if they are angry at the other person, they are angry at themselves. That is why non-self is not a theory, a doctrine, or an ideology, but a realization that can bring about a lot of happiness. (para. 19)

Fifth, the no-self doctrine indicates the existence of store-consciousness. Despite the absence of a permanent and unchangeable self, there is still a psychophysical continuum (Williams, 2000) that makes the "self" somewhat constant during a particular period of time. For example, the "self" tomorrow is different from the "self" today, but certainly it is not a complete difference. More importantly, Williams (2000) notes that this continuum implies possession. For example, $I$, not someone else, possess a particular series of psychophysical features. These are connected with the content of the continuum. To understand this, it is desirable to have some insight into the nature of consciousness. In fact, the nature of consciousness is a very complex concept in Buddhism. However, because of space restrictions, here I limit my discussion to Nhat Hanh's $(1996,2006)$ teachings and interpretations of the nature of the mind on the foundation of what he calls Manifestation Only Buddhism which draws upon "the most important streams of Buddhist thought in India, from the Abhidharma teachings of the Pali Canon to later Mahayana teachings" (2006, p. 11) and upon pieces of work on the nature of consciousness by Buddhist scholar-monks such as the Indian monk Vasubandhu (320-400), the Indian monk Sthiramati (470-550), the Indian monk Asanga (321-390), and the 
Chinese writings of Xuan Zhang (600-664). As for the meaning of Manifestation Only Buddhism, Nhat Hanh (2006) explains, "even though a phenomenon is unmanifested, it is always there, as a seed in our consciousness. Our body, our mind, and the world are all manifestations of the seeds that are stored in our consciousness" (p. 31). As such, unmanifestation does not mean inexistence, and the seeds in our consciousness play the key role in making manifestations.

First of all, it is important to recall the fifth aggregate in the five aggregates that compose selfhood noted earlier. This fifth aggregate is "consciousness" (Mitchell, 2002, p. 38). With reference to the nature of consciousness, Manifestation Only Buddhism offers an elaboration. At a minimum, in this view, human beings possess eight consciousnesses. There are five basic sensory consciousnesses. These five consciousnesses arise when there is contact between a person's five senses and the objects; for example, visual consciousness results from the contact between eye(s) and the corresponding object. Then there is the sixth consciousness or the mind consciousness (manovijnana). Williams (2000) writes, "[T] he mental consciousness (manovijnana) ... experiences mental events, and also synthesizes the data from the senses" (p. 159). This sixth consciousness is grounded in another kind of consciousness; namely the seventh consciousness (manas). Manas has a strong self-love mechanism. The primary job manas does is to love and protect what it believes to be its "self." Therefore, manas is also called by another name: the lover (Nhat Hanh; 1996,, 2006). Because of its "blind love," manas is the centre of delusion. Thus, it is called the "tainted mind" (Williams, 2000, p. 159). Due to the influence of manas, the mind consciousness generally perceives reality in an ego-centric or distorted way. However, manas is not the last kind of consciousness. There is another: the eighth consciousness (alayavijnana), or the store consciousness. Nhat Hanh (2006) writes, "[t]he primary function of store consciousness is to store and preserve all seeds... Maintaining all the seeds, keeping them alive so that they are available to manifest, is the most basic function of store consciousness" (p. 25). As Nhat Hanh (1996, 2006) explicitly and implicitly suggests throughout his books, in this storehouse there are all kinds of karmic seeds accumulated over our lifetime(s). They are imported into the storehouse through the mind consciousness because "mind consciousness is the base of all three types of action [of body, speech, and mind]" (2006, p. 135). These seeds will grow into fruition under favorable causes and conditions. Nhat Hanh notes that the manifestation of an individual's store-consciousness (with karmic seeds as its content) is broadly twofold: a) self and b) external conditions/circumstances where the self is living. As for the latter, Nhat Hanh explains that karmic seeds in our store-consciousness, when they ripen, will create a force that drives us in a particular way. He provides a simple example. If a person constantly cultivates the seeds of (ego-free) concern about people who suffer, he or she will be drawn to a community that serves people in need; contrariwise, if an individual nourishes the seeds of drug addiction, he or she will be driven to those who share the same affliction. Let us return to the continuum with the concept "possession" noted earlier. In light of "store-consciousness," continuum is nothing other than the continuous manifestation of storeconsciousness and its karmic seeds while "possession" means that when karmic seeds ripen, the fruits will occur to the continuum where the original seeds were produced. Williams (2000) shares a similar view. "[T]he karmic result will occur to me because ... I [emphasis original] am the one who possessed the original intention, not someone else" (p. 117). Noticeably, herein, central to the nature of consciousness is the notion of karma (or karmic seeds). Perhaps an elaboration of karma and the law of karma would help clarify further the nature of consciousness.

\section{Law of Karma}

In the simplest sense, the Law of Karma can be understood as the law of Cause and Result. In the Law of Karma Sutra, the Buddha said:

Because of Karmic effects inherited from previous lives, some people are poor, some rich, some happy and some miserable.... Destiny is aggregate [sic] karmic effects from the past. To believe in and practice this Sutra will bring you eternal prosperity and happiness. (translated by Chau, 2008)

In Buddhism, karma refers to our intention of action and intended action. "Action" here "does not refer just to bodily movements, but also includes the actions of speech and mind" (Sadakata, 1997, p. 71). Indeed, 
Anguttara Nikaya, an early Buddhist scripture, quotes the Buddha as saying, "It is volition (cetana) that I call karma; for having willed (cetayitva), one acts by body, speech, and mind" (translated by Bodhi, 2005, p. 146). The law of karma and its operation are described as follows:

It may seem that our deeds, once performed, perish and vanish without leaving behind any traces apart from their visible impact on other people and our environment. However, according to the Buddha, all morally determinate volitional actions create a potential to bring forth results (vipaka) or fruits (phala) that correspond to the ethical quality of those actions. This capacity of our deeds to produce the morally appropriate results is what is meant by kamma [karma]. Our deeds generate kamma, a potential to produce fruits that correspond to their own intrinsic tendencies. Then, when internal and external conditions are suitable, the kamma ripens and produces the appropriate fruits. In ripening, the kamma rebounds upon us for good or for harm depending on the moral quality of the original action. (Bodhi, 2005, p. 146)

Under the law of karma, our suffering or joy is supposed to be the consequence of our (previous) intended action.

In brief, these three Buddhist concepts indicate that it is a deluded view of "self" that gives rise to attachment and craving, which in turn create suffering not only for the respective person but also for others due to his or her egocentricity and the resulting discrimination against others. Craving is thus accompanied by greed, hatred, and delusion. Dangerously, out of these "three poisons", people tend to create bad karma in their attempt to preserve their self/ego which, paradoxically, negatively affects their well-being. Indeed, to quote Nhat Hanh (2006), "The quality of our life depends on the quality of the [karmic] seeds that lie deep in our consciousness" (p. 45). Notably, the concept of store-consciousness suggests that external conditions generally and society specifically are ultimately the manifestation of the mind (both individual and collective), not the other way around. Thus, it is important to have an enlightened mind by having the right view of (no)self, cultivating compassion, and constantly sowing and watering good karmic seeds (Nhat Hanh, 1996; 2006).

\section{No-Self and the "Helping Imperative"}

As noted earlier, behind the perceived neo-imperial imaginary of global citizenship education may be the IOther dualism masked with the helping imperative underpinned by the "politics of benevolence" (Cook, 2012; Jefferess, 2012). For Buddhists, this sense of duality may result from the misbelief in an autonomous self that is independent of others. Provided that this I-Other dualism is not disrupted, or the sense of ego still exists, the fire of greed, hatred, and delusion inside each individual cannot be extinguished. Both socially and individually, this egocentricity, with the resulting three poisons, leads to the attempt to develop society and charitable action that may end up satisfying ego-driven needs rather than truly making a better world. Loy (2003) observes, "If I remain unaware that my sense of duality is a dangerous delusion," or "If I do not struggle with the greed in my own heart, it is quite likely that, once in power, I too will be inclined to take advantage of the situation to serve my own interests" (p. 35). This potential is evidenced by the "helping imperative" in some global citizenship education programs where helpers, in the name of care and aid, are perceived to "utilize the knowledge, and indeed lives, of others as objects of their own knowledge production and skills development" (Jefferess, 2012, p. 35). Indeed, in Jefferess's (2012) words, "I think global citizenship, as the ethical framework for particular kinds of action—or "helping"—serves to mask the structural violence of contemporary global relations" (p. 35). Cook (2012) also writes, "[s]cholars have claimed that the function of travel for Europeans in the colonial era was to realize a fuller sense of self [ego]" (p. 129). Notably, the helping imperative in these programs is underpinned by senses of superiority and inferiority. In truth, the ethical framework of global citizenship may stand in danger of producing "some as privileged, and hence capable of being active global citizens, and some as in need of support, care, aid" (Jefferess, 2012, p. 33), with even a sense of condescension of the former toward the latter (Wright, 2012) .

By contrast, Buddhists have a different view on "help" through their conception of compassion. Buddhist scholar Chogyam Trungpa (1973) holds that compassion "is not feeling sorry for someone. It is 
basic warmth" (p. 97). With compassion, "[w] hen giving [or helping], they [people] should not perform charity as an act of their body alone, but with their heart and mind as well" (Dhammanada, 2002, p. 235), and "[i]t is through such acts of charity that one is able to reduce one's own selfish motives from the mind and begin to develop and cultivate the great virtues of loving kindness, compassion and wisdom" (p. 237). From this stance, the helping imperative discussed above seems to lean towards the opposite direction with the perceived ultimate aim to make the "self/ego" fuller rather than reduce it. Indeed, Cook (2012) observes a development program:

Traveling abroad to do development work seems not to be solely a selfless venture of helping for Western women in Gilgit as the politics of benevolence would have it, but also, as it was in the colonial era, a means for metropolitan women dissatisfied with their lives at home to constitute themselves as full, independent, and authoritative individuals and thereby achieve some sense of personal autonomy. (p. 129)

\section{Skillful Global Citizenship Education}

Insights into Buddhist notions of suffering, no-self doctrine, store-consciousness, and the law of karma imply that it is critical to have an enlightened mind by having the right view of (no)self, cultivating compassion, and constantly nourishing good karmic seeds with kind intention, speech, and action toward other beings (Nhat Hanh, 1996; 2006). On this foundation, for a better and more compassionate world, what I call "skillful global citizenship education" is desirable. At the heart of this education is awareness concerning the truth of suffering and the path of liberation. To this end, skillful global citizenship education should embody three imperatives, namely, skillful awareness of interdependence, skillful compassion, and skillful awareness of intention. Note that, informed by the Eightfold Path which recommends all-encompassing practice (mind, body, and speech), each of these imperatives is also suggestive of simultaneous mind-body-speech practices.

\section{Skillful Awareness of Interdependence}

First of all, students should have skillful or ego-free awareness of interdependence. Note that "awareness of interdependence" is also a major concept in current global education. However, it is not necessarily ego-free. Jefferess (2012) offers an example of ego-driven awareness of interdependence. "From such a standpoint, we must be concerned with the insecurities of others insofar as they might threaten our own (national) security" (p. 33). By contrast, ego-free awareness of interdependence should begin with having the right view of (no)self whereby the fires of greed, ill will, and delusion can be extinguished and hence suffering would cease. To have skillful awareness of interdependence, students should have both conceptual understanding of and embodied experiences of the no-self doctrine with such central concepts as interbeing, nothingness, and nonduality (articulated above). As for knowledge, one way to gain deep conceptual understandings of the no-self doctrine is to practice a Buddhist form of contemplation — the second of Gyamtso's three stages mentioned above. As Vokey (2008) explains:

The task of contemplation is to examine what we have heard thoroughly until we are confident both that we understand "the view" of interdependence-emptiness correctly and [italics original] that it holds up under dialectical cross-examination. In other words, this process is not complete until we can explain and defend to our own complete satisfaction the arguments that undermine naïve belief in the independent existence of self and other. (p. 302)

Besides, it is desirable for learners to have embodied experiences regarding interdependence. This can be achieved through meditation central to which is the practice of mindfulness, "To be mindful of something is to recognize that something is there in the present moment. Mindfulness is the capacity of being aware of what is going on in the present moment" (Nhat Hanh, n.d., para. 18). That is, we should be fully present. For example, washing the dishes is to wash the dishes or drinking a cup of tea is to drink a cup of tea (Nhat 
Hanh, 1976). Discussing the relationship between mindfulness and embodied awareness of interdependence, Nhat Hanh (2006) explains, "[w]hen we live mindfully, observing deeply what is in us and around us, we realize the nature of Interdependent Co-Arising, the interpenetration of all things" (p. 210). Along a similar vein, educator Claudia Eppert (2008) shares some experience of interdependence through what she and Roger Simon (1997) call "witnessing," which Eppert elaborates in the context of Buddhist mindfulness. Accordingly, witnessing is described as "calling for an 'embodied cognizance' [emphasis original] within which one becomes aware of, self-present to, and responsive to something/someone beyond oneself" (p. 98). At the highest stage of witnessing, practitioners would "witness something beyond" (p. 99), or the truth. The truth here is emptiness or "interdependence." It is worth noting that the practice of mindfulness discussed in this section is only suggestive and illustrative, not prescriptive, given the fact that there are possibly various wisdom and meditation traditions leading to skillful awareness of interdependence. Practitioners can decide on what suits them. That said, the practice of mindfulness may be a desirable option for beginners.

Notably, the Buddhist notion of interdependence is not only spatial but also temporal. As for the latter, according to Nhat Hanh $(1996,2006)$, the present encompasses the past and the future. Thus, the practice of mindfulness with a deep look into the "now" helps connect us to the future and the past. This point could inform Western contemporary (global citizenship) education in some way. Especially, as observed by Smith (2006), teaching in the Western tradition "has always operated inordinately in the future tense, within a temporal that privileges the future over the present as well as the past" (p. 25). From a Buddhist stance, it is unrealistic to forget the present moment because for Nhat Hanh (2012) "[w]e can only build the future from the raw materials in the present" (p. 246). In brief, it would be more realistic and productive in terms of raising awareness of interdependence, especially in an globalizing age, if education helps students be more mindful of the "here" and the "now" so that they could have a stronger sense of inter-being, both spatial and temporal.

\section{Skillful Compassion}

Skillful compassion is ego-free or enlightened compassion. As indicated, "compassion" is not absent from current global citizenship practices. However, for Buddhists it may not be ego-free, especially when helpers' "compassion" may be infused with a sense of superiority and condescension (Jefferess, 2012; Wright, 2012). By contrast, skillful compassion is, first of all, not feeling sorry for someone as Trungpa (1973) puts it. Discussing what is called the "four abodes" described in Theravada Buddhism, Eppert (2010) also observes that "[t]he near enemy of compassion is pity" (p. 21). Regarding the "near enemy," she explains, "[t]he near enemy is a likeness to the abode [compassion], but a false likeness, differing from it in important respects" (p. 21). One of the differences, in my view, is that in the former exist egocentricity and superiority. Next, skillful compassion is also comprised of deep empathy, loving and caring kindness, and wishes to release others from suffering (Gyatso, 2001; Nhat Hanh, 1998). According to Gyatso (2001), "[c]ompassion is a mind that is motivated by cherishing other living beings and wishes to release them from their suffering" (p. 174). Equally, Nhat Hanh (1998) posits:

Compassion contains deep concern. You know the other person is suffering, so you sit close to her. You look and listen deeply to her to be able to touch her pain. You are in deep communication, deep communication with her, and that alone brings some relief. (p. 172)

Gyatso (2001) even notes that enlightened compassion, or what he calls great compassion, is not limited to any particular beings. Besides these features, skillful compassion is indicative of non-dualistic generosity. Trungpa (1973) explains, "When a person develops real compassion, he is uncertain whether he is being generous to others or to himself because compassion is environmental generosity, without direction, without "for me" and without "for them" (pp. 98-99). From this perspective, it is desirable to rethink "compassion" in current global citizenship education, especially when, according to Jefferess's (2012) observation, the global citizen is produced as "a particular subject that is constituted by the ability to act, and specifically to "make a better world' for, rather than with, [emphases original] others" (pp. 28-29). 
It is also important to note that compassion in Buddhism does not mean sorrow or misery. Contrariwise, "[t]he near enemy of compassion is grief or sorrow" (McRae, 2012, p. 114). Eppert (2008) offers an explanation. For her, although compassion is not "taking on of another's suffering" and hence not necessarily feeling their pain, it is not "without emotion" (p. 26). In her words, "karunā [compassion] is embodied heartmind awareness and experience that includes an expansiveness of genuine heartfelt concern for the suffering and welfare of another without, however, concurrently being linked to dualistic ... pleasure/pain and egocentric clinging or aversion" (p. 26). Herein, the emotion we have for others' suffering and happiness transcends the duality of pain and pleasure. In this spirit, with true compassion we do not have to be infected with others' pain and help them fight it like "an enemy." Rather, we should understand others' pain and help them recognize and embrace their pain with tenderness and then transform it into peace, to borrow Nhat Hanh's $(2002,2006)$ teachings on how to deal with (seemingly) negative emotions. For that reason, "[c]ultivating compassion should result in a deeper and more extensive tenderness. If it makes us miserable or depressed, then it is not compassion that we are cultivating but rather some kind of grief or sorrow" (McRae, 2012, p. 114).

\section{Skillful Awareness of Intention}

Skillful awareness of intention means being constantly aware of whether our intention is ego-driven or not. As noted earlier, the concepts of store-consciousness and law of karma suggest that society is the product of our mind. More specifically, the social (and individual) well-being is conditioned by the quality of the karmic seeds in our consciousness. For that reason, nourishing and watering kind seeds is vital. Note that karmic seeds come from our intention, action, and speech, and hence to create a better and more compassionate world, students should be reminded of not only their action and speech but also their intention. As aforementioned, there is a perceived confusion between the intention of empowering oneself and that of helping others in some global programs (Cook, 2012; Zemach-Bersin; 2007). Hence, while engaging in social and political movements or helping projects, students should, above all, question their own intention (egocentric or not), or else they may unwittingly end up reproducing things they are working against. In this sense, making a better world is not only social and political but also spiritual because it is connected with the transformation of consciousness, or the inner work. Put differently, a better world is conditioned by the inextricability of spirituality and politics. Hattam (2004) holds a similar view through his notion of "awakening-struggle." "Awakening-struggle demands that politics be considered not as always 'out there, outside of self, exterior', but that politics be simultaneously about both inner and outer transformation, both about self and society, both mind and social structure" (p. 275). Personally, although I acknowledge this dialectical relationship, drawing on Manifestation Only Buddhism I insist that inner transformation generally and awareness of intention specifically should be the primary task. Jones's (2003) position supports my point:

The inner work has primacy over the outer work... Primacy [italics original] here means that social conditions have their ultimate origin in the human condition. And, more profoundly, how we experience social conditions-and create them-is dependent ultimately on the extent of our liberation from self-need. (p. 214)

In the realm of global education, certainly it is pivotal to teach students such skills as critical thinking, problem-solving, and peace and conflict resolution, as embraced in current global citizenship education. However, these skills, in my opinion, are more society-oriented, or more connected with the outer work. Given the importance of volition in enhancing both individual and social well-being, students should also be taught such skills that help them connect more with themselves, with the inner work, in ways that facilitate mind transformation and kind or compassionate intention.

\section{Concluding Comments}


Postcolonial writer Chandra Mohanty (1990) once posed this question, "the task at hand is to decolonize our disciplinary and pedagogical practices. The crucial question is how we teach about the West and its Others so that education becomes the practice of liberation" (p. 191). My hope is that what I call "skillful global citizenship education" - with the three tenets of skillful awareness of interdependence, skillful compassion, and skillful awareness of intention- will help provide an answer to her question. The ultimate message I wish to convey in this paper is that "For a better world, let our non-dualistic mind manifest itself and completely trust it."

\section{Acknowledgments}

I would like to express my deepest gratitude and appreciation to the editors for their careful and exhaustive review of and valuable feedback on my manuscripts. My thanks also go to the two reviewers for their comments on my first version. The earliest version of this paper was presented at the Research Day conference (April, 2012) in the Faculty of Education, University of Alberta.

\section{References}

Andreotti, V. D. O., \& Souza, L. M. T. M. D. (2012). Introduction. In V. D. O. Andreotti, \& L. M. T. M. D. Souza (Eds.), Postcolonial perspectives on global citizenship education (pp. 1-6). New York: Routledge.

Bodhi, B. (2005). In the Buddha's words: An anthology of discourses from the Pali canon. Boston: Wisdom Publications.

Chau, J. (2008). The karma sutra. Retrieved from http://tbsn.org/english2/sutra.php?id $=53 \&$ keyword $=$ \&page $=40$

Cook, N. (2012). 'I'm here to help': Development workers, the politics of benevolence and critical literacy. In V. D. O. Andreotti, \& L. M. T. M. D. Souza (Eds.), Postcolonial perspectives on global citizenship education (pp. 124-139). New York: Routledge.

Dhammanada, K. S. (2002). What Buddhists believe. Kuala Lumpur: Buddhist Missionary Society Malaysia.

Dower, N. (2008). Are we all global citizens or are only some of us global citizens?: The relevance of this question to education. In A. A. Abdi, \& L. Shultz (Eds.), Educating for human rights and global citizenship (pp. 39-53). New York: State University of New York Press.

Ellsworth, E. (2005). Places of learning: Media, architecture, pedagogy. New York: Teachers College Press.

Eppert, C. (2008). Fear, (educational) fictions of character, and Buddhist insights for an arts-based witnessing curriculum. In C. Eppert, \& H. Wang (Eds.), Cross-cultural studies in curriculum: Eastern thought, educational insights (pp. 55-108). New York, London: Lawrence Erlbaum Associates.

Eppert, C. (2010). Heartmind literacy: Compassionate imagining \& the four brahmaviharas. Paideusis, 19(1), 17-28.

Grant, J. M. (2009). Breaking the spells of self: How insights from fairy tales and Buddhist psychology can be applied in the therapeutic practice. In D. Mathers, M. E. Miller, \& O. Ando (Eds.), Self and No-self: Continuing the dialogue between Buddhism and psychotherapy (pp. 206-214). London and New York: Routledge.

Gyamtso, T. (1986). Progressive stages of meditation on emptiness (2d ed.). Oxford: Longchen Foundation. Gyatso, G. K. (2001). Transform your life: A blissful journey. Cumbria, New York: Tharpa Publications.

Harvey, P. (1990). An introduction to Buddhism: Teachings, history and practices. Cambridge: Cambridge University Press.

Hattam, R. (2004). Awakening-struggle: Towards a Buddhist critical social theory. Flaxton: Post Pressed. 
Jefferess, D. (2012). Unsettling cosmopolitanism: Global citizenship and the cultural politics of benevolence. In V. D. O. Andreotti, \& L. M. T. M. D. Souza (Eds.), Postcolonial perspectives on global citizenship education (pp. 27-46). New York: Routledge.

Jones, K. (2003). The new social face of Buddhism: A call to action. Boston: Wisdom Publications.

Loy. D. R. (2003). The great awakening: A Buddhist social theory. Boston: Wisdom Publications.

McRae, E. (2012). A passionate Buddhist life. Journal of Religious Ethics, 40(1), 99-121.

Mitchell, D. W. (2002). Buddhism: Introducing the Buddhist experience. New York: Oxford University Press.

Mohanty, C. (1990). On race and voice: Challenges for liberal education in the 1990s. Cultural Critique, 179208.

Nhat Hanh, T. (1976). The miracle of mindfulness: An introduction to the practice of meditation. Boston: Beacon Press.

Nhat Hanh, T. (1996). Giang luan Duy bieu boc [An interpretation of Manifestation Only Buddhism]. San Jose: La Boi Society.

Nhat Hanh, T. (1997). The heart of understanding: Commentaries on the Prajnaparamita Heart Sutra. Delhi: Full Circle.

Nhat Hanh, T. (1998). The heart of the Buddha's teaching: Transforming suffering into peace, joy, and liberation. New York: Broadway Books.

Nhat Hanh, T. (2006). Understanding our mind. California: Parallax Press.

Nhat Hanh, T. (2008). This is the Buddha's love. Shambhala Sun. Retrieved from http://www.shambhalasun.com/index.php?option=content\&task=view\&id=2882Nhat Hanh, T. (2012). Awakening of the heart: Essential Buddhist sutras and commentaries. California: Parallax Press.

Nhat Hanh, T. (n.d.). Thich Nhat Hanh on loosening the knots of anger. Retrieved from the Shambhala Sun website: http:/ / www.shambhalasun.com/index.php?option= content\&task= view\&id=1756

Odin, S. (1996). The social self in Zen and American pragmatism. Albany: State University of New York Press.

Pawle, R. (2009). The ego in the psychology of Zen: Understanding reports of Japanese Zen Masters on the experience of no-self. In D. Mathers, M. E. Miller, \& O. Ando (Eds.), Self and No-self: Continuing the dialogue between Buddhism and psychotherapy (pp. 45-55). London and New York: Routledge.

Pike, G., \& Selby, D. (1999). In the global classroom 1. Ontario: Pippin Publishing Corporation.

Pike, G., \& Selby, D. (2000). In the global classroom 2. Ontario: Pippin Publishing Corporation.

Rahula, W. (1959). What the Buddha taught: Revised and expanded edition with texts from Suttas and Dhammapada.

Sadakata, A. (1997). Buddhist cosmology: Philosophy and origins. Tokyo: Kosei Publishing Co.

Schattle, H. (2008). The practices of global citizenship. Maryland: Rowman \& Littlefield Publishers.

Smith, D. G. (2006). Trying to teach in a season of great untruth: Globalization, empire and the crises of pedagogy. Rotterdam: Sense Publishers.

Tarc, P. (2012). How does 'global citizenship education' construct its present? The crisis of international education. In V. D. O. Andreotti, \& L. M. T. M. D. Souza (Eds.), Postcolonial perspectives on global citizenship education (pp. 105-123). New York: Routledge.

Taylor, L. (2012). Beyond paternalism: Global education with preservice teachers as a practice of implication. In V. D. O. Andreotti, \& L. M. T. M. D. Souza (Eds.), Postcolonial perspectives on global citizenship education (pp. 177-199). New York: Routledge.

The UK's Department for Education and Skills. (2005). Developing the global dimension in the school curriculum. Retrieved from https://www.education.gov.uk/publications/eOrderingDownload/1409-2005PDFEN-01.pdf

Trungpa, C. (1973). Cutting through spiritual materialism. California: Shambhala publications.

Vokey, D. (2008). Hearing, contemplating, and meditating: In search of the transformative integration of heart and mind. In C. Eppert, \& H. Wang (Eds.), Cross-cultural studies in curriculum: Eastern thought, educational insights (pp. 287-312). New York: Lawrence Erlbaum Associates.

Williams, P. (2000). Buddhist thought: A complete introduction to the Indian tradition. New York: Routledge.

Wright, C. (2012). Postcolonial cosmopolitanisms: Towards a global citizenship education based on 'diverse universalism’. In V. D. O. Andreotti, \& L. M. T. M. D. Souza (Eds.), Postcolonial perspectives on global citizenship education (pp. 47-67). New York: Routledge.

Zemach-Bersin, T. (2007). Global citizenship \& study abroad: It's all about U. S. Critical Literacy: Theories and practices, 1(2), 16-28. 
About the Author

Tram T. A. Nguyen is a Ph.D. candidate at the University of Alberta. She has been working as a research assistant for the Provost and Vice-President of the University of Alberta and also as a research assistant in the Faculty of Education, University of Alberta. She can be reached at ttn1@ualberta.ca. 